\title{
Editorial: green zones, green lines, and green lights
}

\author{
Kirk Dombrowski · Anthony Marcus
}

Published online: 30 January 2009

(C) Springer Science+Business Media B.V. 2009

Keywords War · Arbitrage - Governance $\cdot$ Editorial

As we sit down to write this, two events dominate the international headlines- the full assumption of responsibility for security in the "Green Zone" by Iraqi national forces, marked by the opening of the US embassy in Baghdad; and the Israeli invasion of Gaza, after a week of aerial bombing, via ground forces in what they are calling "Operation Cast Lead." It is tempting to label them together as "one step forward and one step back," but one gets the sense that this is too grand a claim for even the proponents of these actions. In an odd and clearly non-reflective statement, US Undersecretary for Management, Patrick Kennedy announced the opening of the embassy by stating that he had signed the "Certificate of Occupancy" for the new building. Israel needed no such certificate, of course, because it is clear from the beginning that they have no intention of staying. Even the Jerusalem Post, on the eve of the invasion, published a guest editorial pointing out that Israel had refrained from announcing any far reaching political goals for the invasion, noting: "Uprooting Hamas rule from Gaza is beyond Israel's power; it cannot install a new government in Gaza." 1

In both cases, the question is what to make of invasion when done without even the pretence of a will to govern?

One could perhaps be thankful to live in a time when states are making fewer and fewer claims about their own ability to effect change-when management is the key

\footnotetext{
1 Efraim Inbar "Realistic goals for Operation Cast Lead." Jerusalem Post December 12, 2008. http://www.jpost.com/servlet/Satellite?cid=1230733118437\&pagename=JPost\%2FJPArticle\%2FShowFull, accessed January 4, 2009.
}

K. Dombrowski $(\bowtie) \cdot$ A. Marcus

CUNY Graduate Center and John Jay College, CUNY, New York, USA

e-mail: kdombrowski@jjay.cuny.edu 
political term, even the key political office, charged with what may have once been the far headier domain of "state." There is a constant de-escalation of government by government these days, and one gets the sense that it is not just talk-not simply a smoke screen for increasing interference in the daily lives of ordinary folks. Sure governments now have far greater abilities to do so- to step in and mangle ordinary people, not simply with impunity, but with the suddenness that "shock and awe" was meant to convey. Children are taken from unworthy parents with similar fanfare; Third World economies restructured; whole or part-countries invaded. And indeed the mere threat of such drastic measures-domestically, economically, militarily-does itself accomplish a lot of what states are actually said to accomplish. But seldom any longer is there a sense that such actions-like the invasion of Gaza or Iraq - foreclose the need for similar action in the near future.

Just the opposite. If anything seems more clear now than in the past, it is the fact that the invasion of Iraq and the invasion of Gaza are meant to leave things largely as were before. No one in their right mind sees the Israeli invasion of Gaza as intending to put in place some stable form of governance. As preposterous as it sounds, the whole point of the invasion is to elevate the level of social chaos there to even more dizzying heights-reproducing the very conditions that brought Hamas to power. Surveilance? Rationalization? Not a chance; it is simply bulldoze and move on. No one in the Israeli government is claiming any more than this. Both Israel and its US backers seem fairly assured that Hamas will continue to fire rockets until it runs out. And the Israeli Army will continue to level and ruin without any pretense to stopping the ability of Hamas to launch rockets. And Hamas, as a political entity, will survive, and buy more rockets.

Having achieved something similar on a grander scale, the US Army is now doing the reverse. With Iraq having been made largely ungovernable, the job is done, and it seems time to roll up and move on. The same news reports that announced the opening of the embassy also point out that the US State Department has, in response to recent events, asked key US personnel to remain within the embassy, as their safety beyond it cannot be assured.

All of this is not to bemoan the collapse of the state, and certainly not to put the blame for failed states on something as facile as "globalization." In both cases we are talking about some states acting to create situations of ungovernability where other states at least pretend sovereignty in the past. Nor is this process limited to South Asia/the Middle East. As Randy Martin points out, in his An Empire of Indifference (Martin 2007), capitalist states seem less and less interested in sustainable returns; more and more interested in creating situations where small amounts of leverage can produce disproportionate results. The point now, in the eyes of government, is not to effect grand changes by grand gestures, but to create immediate, quite moderate-what the Jerusalem Post called "Realistic"-goals from ever smaller investments. Nobody is looking to make a killing with their killing anymore; just looking to scoop up all the nickels, in the words of one hedge fund manager from the once famous, now defunct firm of Long Term Capital Management (Lowenstein 2001, p. 34). This is the art of the leveraged buy-out, according to Martin. But it requires some preparation. In perfectly rationale markets, arbitrage of this sort is impossible. It requires inefficiency, defect, and 
localism. In its own terms, it requires distorted markets or distortion in general. Profit can then be made by simply linking, by bridging the gap. But there must first exist some irrationality.

Ironically, both invasions are preemptive, though not in any military sense (obviously). Neither the Iraqi regime of Saddam Hussein nor the Hamas government in Gaza represented a military threat to anyone but themselves. Rather, both invasions have much more to do with driving down the cost of future arbitrage, and doing so as cheaply as possible. As far as wars go, the US war in Iraq is relatively inexpensive, and now that it is nearing completion, it leaves behind a political economy that can be moved in one way or another with very small amounts of financial or military input. Where it once required 250,000 or more troops to subdue, the level of internal factionalism means that one could probably control the country with $1 / 5$ th or even $1 /$ 10th that number today, provided the factions are kept at relatively equal strength (the Iraqi regime of the moment being, ideally, one of those factions). The same goes for Gaza. No mass mobilization is required here. Past efforts have left behind a situation where ground forces will meet little if any resistance. Thus far, at the time of this writing, more Israeli soldiers have been killed by "friendly fire" than by armed Palestinian resistance, something that the Israeli Army oddly enough announces with pride. Such divide and conquer leveraging is, of course, nothing new for empires that stretch across the planet, but in the current period when the empire of capital has brought its iron calculus of value into the most distant and narrow capillaries of the world economy and confronts no significant systemic alternatives, we see the remarkable spectacle of leveraging for chaos, rather than order.

The same is true for those in the economy. Where national industries once existed in Iraq, there now exist business of much smaller scale. And here too, the issue is less one of "privatization" than of dispersal and delinking of markets. The ownership of these firms could be cooperative, public, individual, joint-stock. It doesn't matter. What matters is the creation and redistribution of firms across an uneven and disconnected economic landscape, where market makers can, in effect, do just that-make money by making markets. Of course that is a temporary opportunity, one dependent on market un-makers, if you will, remaking these same areas back into potential arbitrage zones periodically. The end result is that in both places, the cost of doing business is going down, while the cost of governing is going up. It is no wonder that nobody is the US or Israel is worried about the state building efforts of the Palestinians or Iraqis.

With this in mind, this issue contains a feature article on "Primitive Accumulation in Modern China" by geographer Michael Webber, with comments from Charles Post, Alvin So, and Michael Perelman. The discussion between Webber and his commentators raises several of these same concerns-what has been the role of the state in fracturing the economy and creating spaces for political and economic arbitrage?; what, asks Webber following Marx, is the place of "primitive accumulation" in industrializing and already industrialized economies?; where and when does the state become primitive, and what holds it in check? Less dramatic than events in the various warzones, the focus here is instead on the more mundane but in the end far more important realm of the transition to a market system in what was already the fastest growing economy in the world. 
In addition, we have an extended review by Gerald Sider that takes as its focus one key element of the ongoing production of political difference within the USNative Americans and that area at the edge of race and class that, while small in economic terms, remains critical to the reproduction of the system of uneven difference as a whole. As Sider points out, the politics of Native American recognition has always been caught up with both intensifying and unsettling the more straight forward economics of race and class in North America. Crucial to Sider's vision, here and elsewhere ${ }^{2}$ is that the idea that states create order is largely a myth, and clearly we agree. Our second review essay, by Avram Bornstein, focuses on two recent ethnographies of Palestine, as they work back and forth between what he calls the "twin issues of dispossession and nation building." As with Webber and Sider, the critical issue is both the question of what sovereignty means in the wake of invasion and dispossession, and, as Bornstein points out, how to write an ethnography that sees these as related, rather than opposed, processes. We also have an extended report on land and dispossession in West Africa by Melis Ece. Here the focus is on how long term processes of dispossession are interwoven into other political processes, including post-colonial state formation. And finally, we have three poems by New York poet David Stock, each of which speaks in a different register to some of the same issues raised by the articles...movement and dispossession, the scale of fate, and the endless effort to get it all into words that actually matter.

\section{References}

Lowenstein, Roger. 2001. When genius failed: The rise and fall of long-term capital management. New York: Random House.

Martin, R. 2007. An empire of indifference: American War and the financial logic of risk management (Social Text Books). Raleigh-Durham, NC: Duke University Press.

Sider, G. 1987. When parrots learn to talk and why they can't: Domination, deception and self-deception in Indian-white relations. Comparative Studies in Society and History 29(1): 3-23.

Sider, G. 1989. A delicate people and their dogs. Journal of Historical Sociology 2(1): 14-40.

Sider, G. 2004. Living Indian histories: The Lumbee and Tuscarora people in North Carolina. Chapel Hill: University of North Carolina Press.

\footnotetext{
2 Sider has, over a long career, argued consistently against the idea that states and empires homogenize and order the peoples they enclose (see Sider 1987, 1989, and 2004 for poignant examples). In this issue he reiterates the point that state domination involves a peculiar mixture of the creation and destruction of difference among those within as well as beyond its borders. Though we are arguing something a bit more specific here, the points raised here owe much to his prior insights.
} 